\title{
Regional freight movement and its impact on air quality: simulation of freight traffic and pavement maintenance operations
}

\begin{abstract}
Freight movement emits greenhouse gases (GHGs) and deteriorates pavement thereby causing additional emissions from pavement maintenance and rehabilitation (M\&R) treatments. This study predicts the carbon dioxide equivalent $\mathrm{GHGs}\left(\mathrm{CO}_{2} \mathrm{e}\right.$ GHGs) emission from simulated freight movement and pavement M\&R operations on regional highways connecting the Canadian provinces of New Brunswick, Prince Edward Island, Newfoundland and Labrador, Nova Scotia and Quebec. This study estimates the equivalent single axle loads (ESALs), CO2e GHGs emissions, and vehicle-distance on every regional highway for a 30 years period. The International Roughness Index (IRI) estimates pavement deterioration curves for highways based on ESALs and observed pavement strength. Linear programming of life-cycle optimization estimates the pavement M\&R operations required to maintain the pavement in good condition during the design period. The simulated freight traffic will emit 1.279 million tons of carbon dioxide gas while emissions from pavement M\&R treatments will be 1.403-1.755 million tons of CO2e GHGs.
\end{abstract}

Keywords: carbon dioxide, maintenance and rehabilitation, pavements, spatial input-output model, simulation
Volume 2 Issue 2 - 2017

\author{
Md Shohel Reza Amin,' Umma Tamima, ${ }^{2}$ Luis \\ E Amador Jiménez ${ }^{2}$ \\ 'Environment \& Computing, Coventry University, UK \\ ${ }^{2}$ Department of Building, Concordia University, Canada
}

\begin{abstract}
Correspondence: Md Shohel Reza Amin, Lecturer in Highway \& Transportation Engineering, Faculty of Engineering, Environment \& Computing, Coventry University, Priory Street, Coventry CVI5FB, United Kingdom, Tel +44-07453171712, Email ac4569@coventry.ac.uk
\end{abstract}

Received: January 28, 2017| Published: March 08, 2017

\section{Introduction}

Road infrastructure has significant impact on trade flow, its growth and development. Freight movement on roads is the major contributor to trade flow in Canada. ${ }^{1}$ The proportion of trade flow via road is increasing because of the reduction in production and distribution costs; income, population and employment growth; and reduction in the cost of freight transport for less risk and higher reliability compared to other modes of freight transport. ${ }^{2}$ This is the case for the interprovincial trade flow of Atlantic Canada. With the exemption of mining activities in Labrador, which are directly connected to Quebec by rail, the rest of the goods produced by New Scotia, Prince Edward Island, Newfoundland and New Brunswick are moving through Highways 1, 2, 7, 15, 16, 102 and 104 to reach their final consumption markets.

Construction and maintenance of road infrastructure cause environment burdens such as greenhouse gases (GHGs) emissions, climate change and wetland conversion etc. These impacts are sometimes seen as localized matters and treated by reducing the levels of certain pollutants, rather than as a systemic problem that needs to be addressed at policy and planning level. ${ }^{3}$ Investment strategies require to address these issues since sustainable development of road infrastructure can only be achieved by predicting and integrating the environmental impacts into the planning system. This study estimates the carbon dioxide equivalent GHGs ( $\mathrm{CO}_{2} \mathrm{eGHGs}$ ) emissions from interprovincial freight movement and pavement maintenance and rehabilitation (M\&R) operations of regional highways in Atlantic Canada.

\section{Literature review}

Transportation asset management decisions are constructed over three pillars-economic development, ecological sustainability, and social desirability. Evaluation of maintenance decisions normally focuses on economic efficiency of transportation policies and investment decisions, rather than looking at environmental impact aspects such as energy consumption and GHGs emissions at different phases of transport infrastructure life-cycle. ${ }^{4}$ The maintenance decisions, based on only the economic measures, ignores the environmental burdens to the climate from M\&R operations. The estimation of GHGs emissions from M\&R operations of road infrastructure is required in support of the direct regulation or market mechanism to internalize environmental externalities of $M \& R$ operations.

Life cycle assessment (LCA) is an analytical technique for assessing potential environmental burdens to climate and is used to measure progress toward environmental sustainability. ${ }^{5,6}$ Keoleian \& Spitzley. ${ }^{7}$ LCA of road infrastructure studies the environmental aspects and potential impacts throughout its life from raw material acquisition through production, use and disposal. ${ }^{5}$ The LCA model includes the acquisition and processing of raw materials, construction processes, maintenance activities, transport of materials and equipment to and from the construction site, construction and maintenance related traffic congestion, overlay roughness effects on vehicular travel and fuel consumption during normal traffic flow and end of life. ${ }^{5}$

Different studies ${ }^{5-8}$ performed LCA to estimate the environmental impacts and energy consumption during the life cycle of pavement. Zhang et al. ${ }^{5}$ developed an integrated LCA and life cycle cost analysis (LCCA) model to calculate the environmental impacts and costs of overlay systems. The model identified that engineered cementitious composite (ECC) overlay system of the rigid pavement reduced GHGs emissions by 32 percent and 37 percent compared to the concrete overlay system and the HMA overlay system, respectively, over the entire 40 year life cycle of the rigid pavement. ${ }^{5}$ 
Chappat \& Bilal $^{7}$ reported an in-depth analysis of energy consumption and GHGs emissions over 20 different paving product types. Their comparisons revealed that Portland Cement Concrete paving materials and processes demanded the most energy, followed by hot mix asphalt paving. The report also showed that cold in-place recycling is the least energy intensive process. The report estimated that traffic consumed between 10 and 345 times the energy of road construction and maintenance over the period of 30 years depending on whether the traffic was light or heavy. ${ }^{7}$ Similar to Chappat \& Bilal, Terrel \& Hicks ${ }^{9}$ identified that hot in-place recycling utilized less energy than hot mix asphalt paving.

Drochies $^{6}$ examined the entire cycle of pavement construction from production to final construction (production, extraction, manufacture, transport and laying) of different types of road pavement structures over a thirty year service life with respect to energy consumption and GHGs emissions. The examination concluded that binder and mix manufactures are mainly responsible for GHGs emissions of hot mix bituminous pavements and continuous reinforced concrete pavements. ${ }^{6}$

Chevoits \& Galehouse ${ }^{8,9}$ evaluated the energy efficiency and GHGs emissions from pavement's life extension and revealed that pavement preservation treatments significantly reduced energy use and GHGs emissions compared to traditional rehabilitation and reconstruction strategies. Miller \& $\mathrm{Bahia}^{10}$ also revealed that proactive maintenance was the least energy intensive process because minimal improvements were made to the pavement structure and surface course. The Canadian Construction Association (2005) developed a "Road Rehabilitation Energy Reduction Guide for Canadian Road Builders" to provide information on methods to reduce energy usage during road construction and maintenance operations. None of these studies considered the simulated freight traffic based on future trade flow and resulting M\&R operations in the LCA models.

\section{Methodologies}

\section{Spatial input-output modeling}

Traditional forecasting of freight transport ignores different critical issues because of the stable relationship between gross domestic product and traffic forecasting. Moreover, traffic forecasting was mainly concerned with urban traffic in which freight transport has a negligible contribution. ${ }^{11}$ The basic mechanism of predicting the freight travel demand is the prediction of potential volumes of freight traffic, which is later distributed among various types/modes of transportation according to their performance in terms of cost, time and reliability. After that, these modes are assigned to different routes based on ton-km ratio which is later translated into vehicle-km ratio.

This study estimates the inter-provincial trade flow based on a spatial input-output model and provincial capitals are considered as points of origins and destinations of trade flow. The spatial inputoutput model adopted in this study, includes the trade flow of goods and services for which the factors of production are private consumption, gross investment, government spending (both federal and provincial), and net exports. Gross investment includes non-residential investment (expenditure for firms for machines and tools), residential investment (expenditure by households and firms on apartments, buildings and factories), and change in inventories in a given period. Government spending consists of federal expenditure on provinces, provincial expenditure, and federal government transfers of funds to provincial governments. Net export is the summation of net international export (International export-international import) and net domestic export (domestic export-domestic import). Production of goods and services, and factors of production are included in the spatial input-output model as the sectors. ${ }^{12}$

In principle, every sector requires input/production factors from other sectors except in the case of basic productive activities. Induced production at each province can be calculated given the amounts of final demand in one or more sectors of all other provinces, which is allocated among provinces through spatial distribution functions. The allocation of induced production among different provinces according to demand eventually causes flows of goods and services among different provinces through provincial road infrastructures. ${ }^{12}$

The total demand for sector $n$ in a particular province $i\left(T D_{i}^{n}\right)$ is calculated by Equation 1 .

$$
T D_{i}^{n}=\sum I D_{i}^{m n}+E D_{i}^{n} \quad \forall I D_{i}^{m n}=\left(P_{i}^{n, t}=P_{i}^{n, t-1}+P_{i}^{n, t}{ }^{n} I_{i}^{n, t}\right) * P D_{i}^{m n}
$$

$$
P D_{i}^{m n}=P \operatorname{Dmin}^{m n}+\left(P \operatorname{Dmax}^{m n}-P \operatorname{Dmin}^{m n}\right) * \exp \exp -\delta^{m n} U_{i}^{n}
$$

$\mathrm{P}_{\mathrm{i}}^{\mathrm{n}, \mathrm{t}-1}=$ Production of sector $n$ in province $i$ for time $(t-1)$

$\Delta \mathrm{P}_{\mathrm{i}}^{\mathrm{n}, \mathrm{t}}=$ Growth of production of sector $n$ in province $i$ between time $(t-1)$ and $t$

$$
I_{i}^{n, t}=\frac{A_{i}^{n, t}}{\sum_{i} A_{i}^{n, t}}=\text { Proportion of the increment of } n \text { allocated to }
$$

province $i$ for time $t$

$$
\begin{aligned}
& \mathrm{A}_{\mathrm{i}}^{\mathrm{n}, \mathrm{t}}=\text { Attractor of sector } n \text { in province } i \text { for period } t \\
& E D_{i}^{n}=\text { exogenous demand for } n \text { from zone other than five }
\end{aligned}
$$
provinces and considered as zero

$\mathrm{PD}_{\mathrm{i}}^{\mathrm{mn}}=$ amount of production of sector $n$ demanded by a unit of sector $m$ in zone $i$

$P \min ^{m}{ }_{n}=$ minimum amount of $n$ required by a unit production of $m$

$\operatorname{PDmax}^{\mathrm{mn}}=$ maximum amount of $n$ required by a unit production of $m$

$\ddot{\mathrm{a}}^{\mathrm{mn}}=$ elasticity parameter of $m$ with respect to the cost of input $n$

$$
\mathrm{U}_{\mathrm{i}}^{\mathrm{n}}=\text { disutility of } n \text { in } i \text {, where } U_{i}^{n}=\frac{P D_{i}^{m n}}{\left[\min \min \left(P D_{i}^{m n}\right)\right]^{\mathrm{e}}}
$$

$\theta^{\mathrm{m}}=$ degree of scaling. If utility function is fully scaled $\theta^{m}=1$, otherwise zero.

The demand for production of good $n$ in province $j$ is the product of the total demand for $n$ and the probability that the production of $n$ in province $j$ is demanded by other provinces (Equation 2). ${ }^{3}$ 


$$
\begin{aligned}
& P_{j}^{n}=\sum_{i} T_{i}^{n} * \operatorname{Pr}_{i j}^{n} \quad \forall \operatorname{Pr}_{i j}^{n}=\frac{\left(A_{j}^{n}\right)^{\alpha^{n}} * \operatorname{expexp}-\beta^{n} \tilde{U}_{i j}^{n}}{\sum_{j}\left(A_{j}^{n}\right)^{\alpha^{n}} * \exp \exp -\beta^{n} \tilde{U}_{i j}^{n}} \\
& \sim^{n} \\
& U_{i j}=\frac{U_{i j}^{n}}{\left[\min \left(U_{i j}^{n}\right)\right]^{\dot{\mathrm{e}}}}
\end{aligned}
$$

Where $\operatorname{Pr}_{i j}^{n}$ is the probability that the production of sector $n$ demanded in province $i$ is located in province $j ; A_{j}^{n}$ is the attractor term for the production of $n$ in $j ; \alpha^{n}$ is a parameter that regulates the relative importance of the attractor versus the utility function in the location of sector $n ; \beta^{n}$ is the dispersion parameter of the multinomial logit model; and $U_{i}^{n}$ is the utility function of sector $n$ between province $i$ and $j$.

Freight demand for transporting goods and services among different provinces is estimated following Equation $3 .{ }^{6}$

$$
F_{i j}=\sum_{n}\left(P_{i j}^{n} \frac{\text { vol }^{n} p c^{n}}{\text { time }^{n}}+P_{j i}^{n} \frac{\text { vol }^{n} c p^{n}}{\text { time }^{n}}\right)
$$

Where $F_{i j}$ is the freight flow from province $i$ to province $j ; P_{i j}^{n}$ is the production of sector $n$ located at province $j$ and consumed in province $i ; P_{j}{ }^{n}$ is the production of sector $n$ located at province $i$ and consumed in province $j ; v l^{n}$ is the value-to-volume factor for the economic flow of sector $n$; time ${ }^{n}$ is the time factor for the economic flow of sector $n ; c p^{n}$ is the proportion of economic flow of sector $n$ that moves in the direction consumption to production; $p c^{n}$ is the proportion of economic flow of sector $n$ that moves in the direction production to consumption. ${ }^{13}$

\section{Factors of transportation modeling}

The peak capacities of each link of the selected highways were calculated based on the method adopted by the British Columbia Ministry of Transportation ${ }^{14}$ in the Trans-Canada Highway 1-Malahat Corridor Study to calculate peak capacity. The peak capacity of highway $1,2,7,15,16,102$, and 104 is $3469,3290,3440,3551$, 3358,3616 and 3499 vehicles per hour respectively. Since this paper is concerned with freight transport, the transportation attributes of trucks were considered for the traffic simulation. The operating cost, which includes fixed cost, distance-related cost, time-related cost, possible charges and energy cost, was calculated based on Equation 4. ${ }^{12}$ The waiting and travel time values of truck drivers is assumed to be zero since traveling and waiting time are within their salary. This study ignores the self-employed truckers.

$$
C_{\varphi}=C_{F}+C_{T}+C_{D}+C_{c}+C_{e}
$$

$C_{F}=$ The fixed operating cost of a truck once for every trip made; usually refers to administrative costs and loading/unloading cost. The average fixed cost for a 6 -axle truck at $10 \%$ profit margin is CAD 1.93per km (CAD 2.094per km for Quebec, CAD 1.885per $\mathrm{km}$ for New Brunswick, CAD 1.838per km for Nova Scotia, CAD 1.848per $\mathrm{km}$ for Prince Edward Island, and CAD 1.985per $\mathrm{km}$ for Newfoundland and Labrador). ${ }^{15}$
$C_{T}=$ Drivers' salaries and capital payments. According to the Economic Analysis Directorate, ${ }^{16}$ the truck would either be sold or retired for use as an urban pickup and delivery unit after 500,000 to 750,00 miles (or 800,000 to 1.2 millionkm). The trucks operate for an average of 8 years considering 100,000miles $(160,000 \mathrm{~km})$ of driving per year. The average purchasing cost of a 6-axle truck for the selected five provinces is CAD 126,000 (Quebec CAD 130,000, New Brunswick CAD 121,000, Nova Scotia CAD 121,000, Prince Edward Island CAD 133,000, and Newfoundland and Labrador CAD $121,000) .{ }^{16}$ The capital payment and driver's salary is CAD 21.60per hour considering 270 working days per year and 10 hours per day for operating the truck by the drivers. ${ }^{12}$

$C_{D}=$ Operating cost CAD 1.4perkm, ${ }^{15}$ usually includes tires, spares, maintenance, lubricants, and others. This cost varies by link type.

$C_{c}=$ Charges paid by driver for tolls, parking, duties, etc. The charges of tolls, parking and duties were assumed to be zero.

$C_{e}=$ energy cost. The energy cost of the truck is calculated by Equation 5 based on the minimum and maximum consumption of energy and optimal speed. ${ }^{17}$ Here the price of gas is CAD 3.65per gallon. An aerodynamic 18 -wheel truck with a smooth side van trailer, 80,000 pounds gross vehicle weight, operates at 60 miles per hour. This results in a truck getting about 6 miles per gallon. ${ }^{18,12}$

$$
C_{e}=\left[e d_{o}^{\min }+\left(e d_{o}^{\max }-e d_{o}^{\min }\right) * \exp \left(-\delta^{o} V_{o}\right)\right] p e_{o}
$$

$e d_{o}^{\min }=\quad$ Minimum consumption of energy per mile when the truck travels at free flow speed

$V_{o} \quad=$ Maximum consumption of energy per mile when the truck travels at a speed close to zero

$$
\begin{aligned}
& V_{o}=\text { Speed of vehicle }(m p h) \\
& p e_{o}=\text { Price of unit of energy (CAD per gallon) }
\end{aligned}
$$

Minimum and maximum parameters of the elastic trip generation function in the transport model were taken as 0.21 and $0.27 .{ }^{19}$ The maximum trip generation rate is the maximum number of trips that a trip maker is willing to make in the time period of the simulation when the travel disutility tends to zero. ${ }^{12}$

Different categories of straight trucks and Tractor trailers (CAT 5-13 of Federal Highway Administration, FHWA) are assumed to carry an average CAD 1million worth of goods and services. According to the Canadian Annual Vehicle Survey 2009, ${ }^{20} 54,871$ registered trucks (weight 15tons and over) of the selected five provinces made trips of 4,465.1 million vehicle-km. On the other hand, trade flow among these five provinces was CAD 97,125million during 2009. If we consider that $57 \%$ of interprovincial trade flow was carried out by truck (Statistics Canada 2009), a truck carries tentatively CAD\$ 1million worth of goods and services. ${ }^{12}$

\section{Pavement performance modeling}

Pavement performance modeling was based on the mechanistic modeling of roughness progression by Equation $6 .{ }^{21,22}$ Equation 6shows that roughness progression (International Roughness Index, $I R I)$ is the function of initial as-built quality $\left(I R I_{0}\right), E S A L s$ at time $t\left(E S A L_{t}\right), S N$, and mean environmental exposure (Thornthwaite moisture index, $m$ ). However, the decision variable of predicting IRI is ESALs in this method. The ESALs are calculated based on the 
predicted $A A D T$ and locally observed truck distributions combined with truck factors. The Federal Highway administration (2011) defines the distribution and truck factors for truck classes of 4, 5, 6, 7, $8,9,10,11,12$ and $13 . .^{13}$

The $S N$ follows the computation method developed by the 1993 AASHTO Flexible Pavement Structural Design. The actual layer thicknesses are converted to $S N$ using a layer coefficient that represents the relative strength of the construction materials in that layer (AASHTO 1993). Additionally, all layers below the surface layer are assigned a drainage coefficient that represents the relative loss of strength in a layer due to its drainage characteristics and the total time it is exposed to near-saturation moisture conditions AASHTO 1993.

The Thornthwaite moisture index is identified as $0.07,0.074$ and 0.08 for the three environmental zones with a moisture index of 60 , 80 and 100 within APC, respectively.23 The $I R I_{0}$ is set between 0.7 and $1 \mathrm{~m} / \mathrm{km}$ depending on the highway and coefficient $a$ is set to $265 .{ }^{13}$

$$
I R I_{t}=e^{m t}\left[I R I_{0}+a(1+S N C)^{-5} \cdot N E_{t}\right]
$$

Roughness (IRI) was rescaled to produce a 0 to 100 roughness index (PRI). Measures of rutting and linear cracking were combined to produce a surface distress index (SDI). Observed historical trends of structural strength (FWD and Dynaflect) were used to produce a structural adequacy index (SAI). These indexes were combined to produce a Pavement Condition Index. ${ }^{22}$

\section{Linear programming of pavement management system (PMS)}

Lifecycle optimization to achieve and sustain acceptable mean network condition $(\bar{Q})$ at a minimum cost is used to find required levels of funding for Montreal road network (Equation 7 and 8). The maximization of total network condition under such a budget is then used to find optimal strategic results for pavement management (Equation 9 and 10). This formulation relied on a decision tree containing all possible paths of pavement condition across time, after hypothetically receiving available treatments. ${ }^{24}$ This tree is based upon a transfer function used to estimate condition $\left(Q_{t i}\right)$ as a convex combination based on the decision variable and the effectiveness or deterioration of the specific link on time $t$ (Equation 11). ${ }^{25}$

The objective function is to minimize cost $(Z)$ and maximize pavement condition of the road network

$$
\begin{aligned}
& \text { [ } \left.\sum_{t=1}^{T} \sum_{i=1}^{a}\left(L_{i} Q_{t i}\right)\right] \\
& \text { MINIMIZE } \quad \mathrm{Z}=\sum_{t=1}^{\mathrm{T}} \sum_{i=1}^{a} \sum_{j=1}^{o} C_{t j} X_{t i j} L_{i} \\
& \text { Subject to: } \sum_{t=1}^{T} \sum_{i=1}^{a} L_{i} Q_{t i} \geq(\bar{Q}) \sum_{i=1}^{a} L_{i} \\
& \text { MAXIMIZE } \quad \sum_{t=1}^{T} \sum_{i=1}^{a}\left(L_{i} Q_{t i}\right) \\
& \text { Subject to: } \quad \mathrm{Z}=\sum_{t=1}^{\mathrm{T}} \sum_{i=1}^{a} \sum_{j=1}^{k} C_{t j} X_{t i j} L_{i} \leq \mathrm{B}_{\mathrm{t}} \\
& \sum_{j \in J_{t i}} X_{t i j} \leq 1
\end{aligned}
$$

$$
Q_{t i j}=X_{t i j}\left(Q_{(t-1) i j}+E_{i j}\right)+\left(1-X_{t i j}\right)\left(Q_{(t-1) i j}+D_{i t}\right)
$$

Where $X_{t i j}$ is 1 if treatment $j$ is applied on road segment $i$ at year $t$, zero otherwise; $Q_{t i}$ is condition Index for road segment $i$ at year $t$; $Q_{t i j} i s$ condition Index of road segment $i$ at year $t$ for treatment $j ; Q_{(t-1)}$ ii is condition Index of road segment $i$ at year $(t-1)$ for treatment $j ; C_{t}$ is cost $(\$)$ of treatment $j$ at year $t ; L_{i}$ is length of road $(\mathrm{km})$ for road segment $i ; E_{i j}$ is improvement ( + ) on road segment $i$ from treatment $j$, $D_{i t}$ is deterioration (-) on road segment $i$ at time $t, B_{t}$ is budget at year $t$.

Pavement maintenance and rehabilitation activities, applied on the highways during the 30 years, have been presented in Table $1 .^{12}$

Table I Treatment and Operational Windows Used in Network-level Tradeoff Analysis

\begin{tabular}{ll}
\hline Treatment & Operational window \\
\hline $\begin{array}{l}\text { Crack-sealing } \\
\text { Micro-surfacing (max. of } 2\end{array}$ & Crack $<=8 . \mid 3$ and Crack $\mid>=90$ \\
consecutive) & Arterial: $|\mathrm{RI}|<=2$ and PSDI $3>=65$ \\
Minor Rehab (e.g. thin overlay) & Arterial: $\mid \mathrm{RI}<=2.5$ and PSDI $>=50$ \\
Major Rehabilitation & $\mid \mathrm{RI}>=2.0$ SAI4 $<=65$ \\
Reconstruction &
\end{tabular}

Note: ${ }^{2}$ CRACK $=\%$ of surface without cracks, ${ }^{2}$ rutting $=\%$ of surface with rutting, ${ }^{3} \mathrm{PSDI}=$ pavement distress index and ${ }^{4} \mathrm{SAI}=$ structural adequacy index

\section{GHGs emissions from pavement maintenance and rehabilitation activities}

The GHGs emissions from pavement treatments per unit area of pavement surface were calculated based on the standard developed by Chappat \& Bilal, ${ }^{26}$ Chehovits \& Galehouse ${ }^{27}$ and Dorchies. ${ }^{28}$ Dorchies $^{28}$ applied the GHGs emissions standard on highway 40 in Montreal (from the interchange at Côte de Liesse to St-Charles Boulevard), which was completely reconstructed during the period of 2003-2006. This part of the highway 40 is one of the busiest highways in Quebec with a designed value of 200million ESALs for a 30 years life span.

These researchers ${ }^{29,30}$ determined the pavement structure and the associated maintenance scenarios based on the French administration LCPC-SETRA design method (LCPC- SETRA 1994). The LCPCSETRA design method used a maintenance schedule such as a new layer of HMA (hot mix asphalt concrete) every 8 to 12 years on flexible pavement, a surface overlay after 15 years, and a partial reconstruction or reinforcement overlay after 28 years on rigid pavements. ${ }^{23}$ The elasticity modulus for the road bed and granular sub grade of the pavement structure was considered as $50 \mathrm{MPa}$ and $100 \mathrm{MPa}$, respectively.

These researchers collected environmental analysis data for bitumen from Eurobitume, and for cement and steel from the Athena Sustainable Materials Institute. ${ }^{31,32}$ These studies also considered different average distances for manufacturing one metric ton of HMA. For example, they estimated an average distance of $150 \mathrm{~km}$ between the refinery for bitumen production and the mixing plant, $150 \mathrm{~km}$ between the cement plant and the concrete plant, $800 \mathrm{~km}$ between the steel factory and the site, $5 \mathrm{~km}$ between the aggregate quarry and the manufacturing site, and $50 \mathrm{~km}$ between the manufacturing site and the construction site. ${ }^{8,23}$

\section{Interprovincial trade flow and freight traffic modeling}

The total demand (Equation 1) and production (Equation 2) of the 
five selected provinces for the period of 2012-2041 were predicted based on the interprovincial trade flow data (1986-1996) collected from the Institut de la Statistique Quebec (Figure 1). Since the study is mainly concerned with the truck trade flow, the truck share of the interprovincial trade flow was incorporated during the calculation.

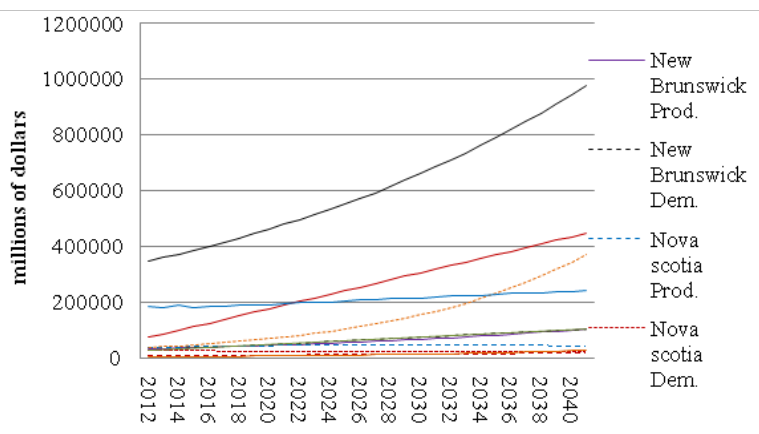

Figure I Total demand and production of five provinces during 20I2-204I.

Figure 1 reveals that the predicted production and demand of goods and services in New Brunswick is the same during the period of 2012-2041. In Nova Scotia, the total demand is decreasing while total production is increasing (increasing at an increasing rate until 2030 and then increasing at a decreasing rate) and demand is far lower than production during the same period. In Newfoundland and Labrador, the total demand exceeds total production during the estimation period. Production in Newfoundland and Labrador is exponentially increasing, while demand is linearly increasing. In Quebec, the total production is far higher than total demand and increasing at a higher rate than that of demand during the design period. In Prince Edward Island, the total demand is increasing at a higher rate than that of production.

\section{Data analysis}

\section{Integration of spatial input-output and transportation modeling}

Freight traffic was simulated using TRANUS, which calculated Table 2 Predicted ESALs per year for New Brunswick regional highways' that trucks would travel 334.722 million truck-km per year. For this interprovincial trade flow, the total operating cost and energy consumption per year will be CAD 2,579.63million and CAD 91.69million respectively.

The Annual Average Daily Truck Traffic (AADTT) for interprovincial trade flow was estimated as 2397 for highway 1, 8008 for highway 2, 934 for highway 7, 599 for highway 15, 569 for highway 16, 226 for highway 102, and 183 for highway 104 (Figure 2). This reveals that the major impacts of the AADTT on these selected highways are contributed by truck flows for interprovincial trade among the selected five provinces (Figure 2).

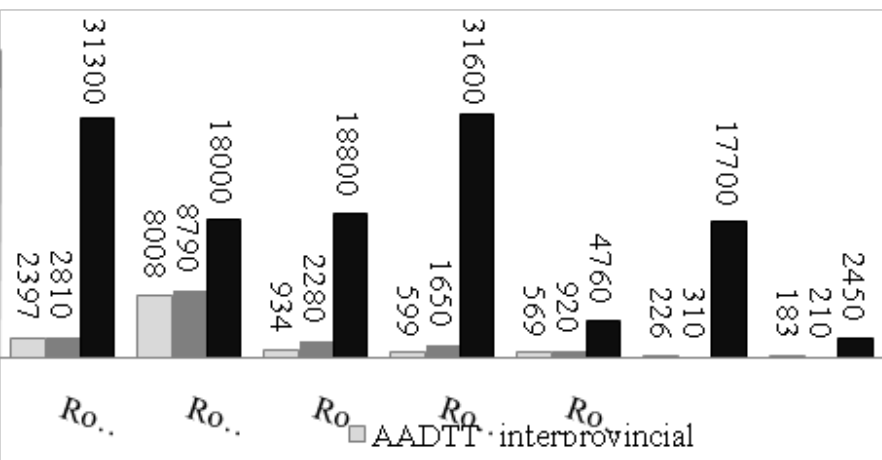

Figure 2 Annual average daily traffic (AADT) of all vehicles, trucks and interprovincial trucks.

\section{Pavement performance and maintenance modeling}

Accumulated traffic loading in equivalent single axle loads $\left(N E_{t}\right)$ was calculated (Table 2) based on the predicted number of trucks per year (AADTT) (Figure 3) and locally observed truck distributions combined with truck factors of $(0.45,1.18,3.25,0.99,2.33,5.91$, 4.7) for truck classes 5, 6, 7, 8, 9, 10 and 13 according to the Federal Highway administration classification (FHWA 2011). Finally, cumulative equivalent single axle loads for the predicted truck traffic during the period of 2012-2041 was calculated and plotted in Figure 4.

\begin{tabular}{|c|c|c|c|c|c|c|c|c|c|}
\hline Truck category (FHWA) & \% Trucks & Truck factor & Route & Route & Route & Route & Route & Route & Route \\
\hline & & & I & 2 & 7 & 15 & 16 & 102 & 104 \\
\hline 5 & 8.2 & 0.45 & 12385 & 41370 & 4825 & 3092 & 2940 & 1169 & 943 \\
\hline 6 & 5.7 & 1.18 & 22574 & 75409 & 8794 & 5637 & 5359 & 2132 & 1719 \\
\hline 7 & 0.4 & 3.25 & 4363 & 14575 & 1700 & 1089 & 1036 & 412 & 332 \\
\hline 8 & 2.7 & 0.99 & 8971 & 29968 & 3495 & 2240 & 2130 & 847 & 683 \\
\hline 9 & 52.6 & 2.33 & 4|| $34 \mid$ & 1374059 & 160247 & 102710 & 97644 & 38843 & 31331 \\
\hline 10 & 28.6 & 5.91 & 567302 & 1895035 & 221005 & 141653 & 134666 & 53571 & 43210 \\
\hline 13 & 1.8 & 4.7 & 28394 & 94849 & 11062 & 7090 & 6740 & 2681 & 2163 \\
\hline ESALs per year & & & $|05533|$ & 3525266 & 411129 & 263511 & 250514 & 99656 & 80382 \\
\hline
\end{tabular}

Deterioration curves (IRI) (Equation 5, Figure 4), based on the predicted amount of traffic loads (ESALs per year), were developed for the pavement management system following those proposed by Paterson \& Attoh-Okine ${ }^{31}$ and previously applied in New Brunswick by Amador-Jiménez \& Mrawira. ${ }^{32}$ The IRI of the selected highways was calculated for different environmental zones since those highways are within environmental zones for different moisture indices (Highway 1 with 100 and 80 moisture index; Highway 2 and 7 with 100,80 and 60 moisture index; Highway 15 with 80 and 60 moisture index; Highway 16 with 60 moisture index; Highway 102 with 100 moisture index; and Highway 104 with 80 moisture index). ${ }^{33}$ 


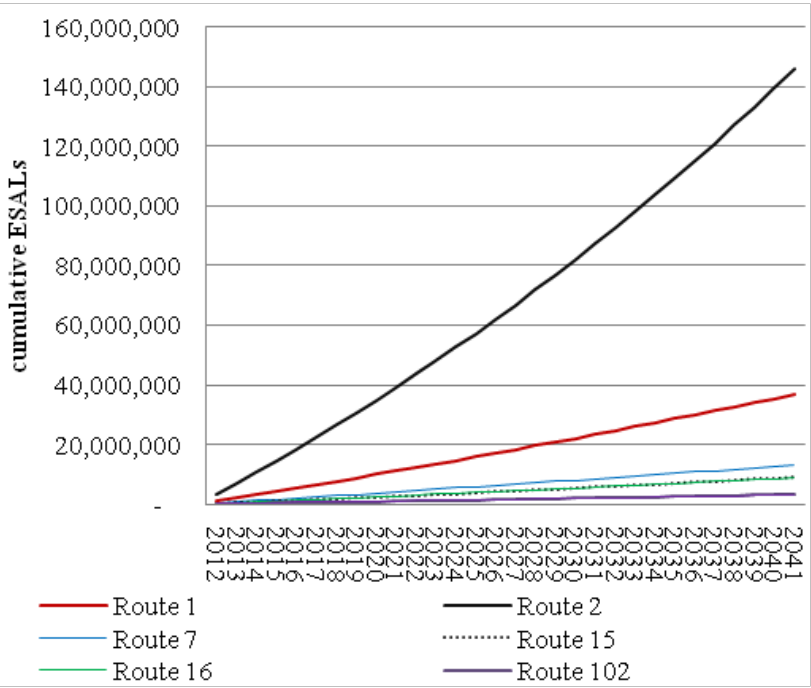

Figure 3 Cumulative equivalent single axle loads on selected routes.

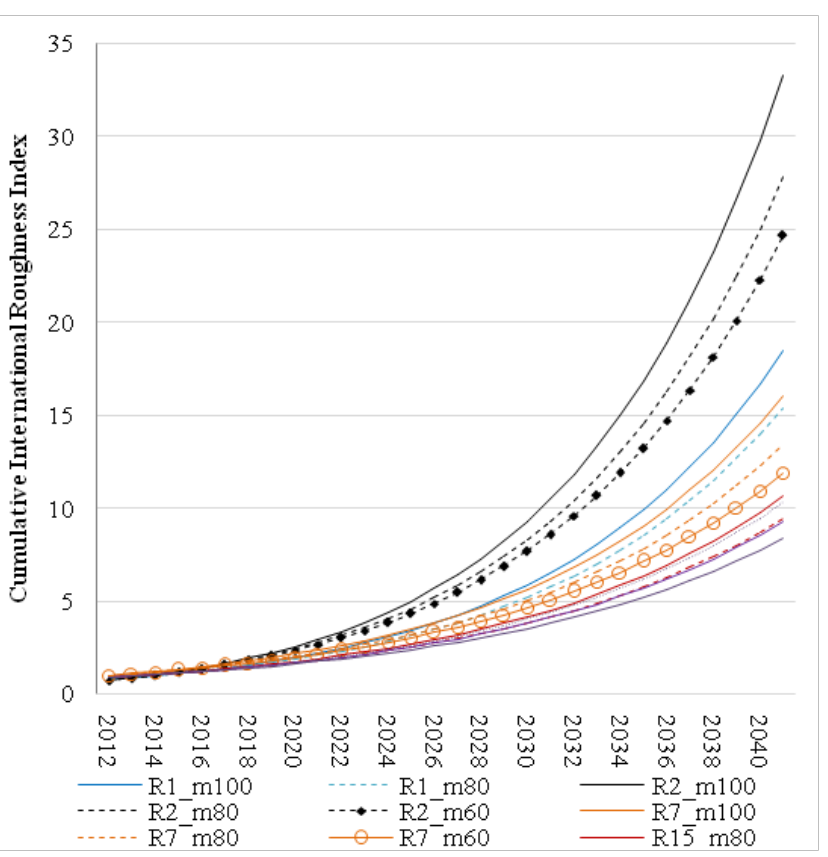

Figure 4 Cumulative international roughness index for moisture index of 60 , 80 and 100.

Table 3 explains the details regarding the links of the selected routes requiring different types of pavement treatments during the design period. Treatment years represent the years of pavement

Table 3 Pavement surface treatments of links of selected routes maintenance carried, while control section implies the number of links of each route that required pavement treatments during different time periods. Table 3reveals that single chip sealing will be required for $7,074 \mathrm{~km}$ of Highway $1,1253 \mathrm{~km}$ for Highway 2, 2246km for Highway 7, $2985 \mathrm{~km}$ for Highway $15,1.44 \mathrm{~km}$ for Highway $16,3.68 \mathrm{~km}$ for Highway 102, and $1698 \mathrm{~km}$ for Highway 104. Double chip sealing will be required for $246 \mathrm{~km}$ of Highway $1,14.9 \mathrm{~km}$ for Highway 2, $1689 \mathrm{~km}$ for Highway $7,0.56 \mathrm{~km}$ for Highway 15 , and $1.48 \mathrm{~km}$ for Highway 16.

Micro-surfacing pavement treatment will be required for 18.68 $\mathrm{km}$ of Highway $1,164.8 \mathrm{~km}$ for Highway 2, 27.28km for Highway $7,100.14 \mathrm{~km}$ for Highway $15,2.64 \mathrm{~km}$ for Highway $16,121.22 \mathrm{~km}$ for Highway 102, and $80.48 \mathrm{~km}$ for Highway 104 (Table 3). Minor rehabilitation (hot in-place recycling, HIR) will be required for $11.48 \mathrm{~km}$ of Highway 1, $100.06 \mathrm{~km}$ for Highway 2, 32.8km for Highway 7, $58.24 \mathrm{~km}$ for Highway $15,5.18 \mathrm{~km}$ for Highway 16, $126.76 \mathrm{~km}$ for Highway 102, and $48.78 \mathrm{~km}$ for Highway 104 . Major rehabilitation will be required for $168 \mathrm{~km}$ of Highway $1,113.8 \mathrm{~km}$ for Highway 2, 3.84km for Highway 7, 4.36km for Highway 15, 6.96km for Highway 16, $1.8 \mathrm{~km}$ for Highway 102, and $5.34 \mathrm{~km}$ for Highway 104 (Table 3). Reconstruction will be required for $5.44 \mathrm{~km}$ of Highway 1, 50.26km for Highway 2, 3.2km for Highway 7, $5.1 \mathrm{~km}$ for Highway 15, 14.48km for Highway 16, and 5.8km for Highway 102 (Table 3).

\section{The carbon footprint of forecasted freight traffic and traffic induced pavement maintenances}

To calculate the 'carbon footprint', this study estimated $\mathrm{CO}_{2}$ emissions from the fuel consumption by the anticipated truck movement and carbon dioxide equivalent $\left(\mathrm{CO}_{2} \mathrm{e}\right)$ GHGs emissions from pavement maintenance activities due to the interprovincial trade flow during a period of 30 years. This study calculated 4.19 million gallons of fuel consumption per year due to the interprovincial truck movement on the selected highways, of which 2.6million gallons fuel will be consumed on Highway 2, 0.78million gallon on Highway 1, 0.3 million gallon on Highway 7, 0.19million gallon on Highway 15, 0.18 million gallon on Highway 16, 0.07 million gallon on Highway 102 and 0.06 million gallon on Highway 104. This study estimated the total fuel consumption assuming that the average mileage of diesel-driven truck was 6 miles per gallon. During the period of 30 years (2012-2041), 125.61million gallons of fuel will be consumed for this interprovincial truck flow among New Brunswick, Nova Scotia, Newfoundland and Labrador, Quebec, and Prince Edward Island, which will be valued at CAD 2750.96million. In addition, per year $\mathrm{CO}_{2}$ emissions will be 42625.28 metric tons for the predicted interprovincial truck movement, which will be equal to 1.279 million metric tons of $\mathrm{CO}_{2}$ emission during the projected 30 years. This study adopted that the $\mathrm{CO}_{2}$ emission from diesel-driven freight transport was 10.18 grams per gallon. ${ }^{34}$

\begin{tabular}{|c|c|c|c|c|c|c|c|}
\hline Route & & One cheap seal & Double cheap seal & Micro surfacing & Minor rehab. & Major rehab. & Reconstruction \\
\hline \multirow[t]{4}{*}{1} & Total Length $(\mathrm{Km})$ & 7073.7 & 246 & 18.68 & 11.48 & 168 & 5.44 \\
\hline & Treatment year & $\mathrm{I}, 2,3,4,5$ & 2,3 & $1,2,3,4$ & $\mathrm{I}, 2,3$ & 3 & 4,6 \\
\hline & & $6,7,8,9,10$ & & $5,8,9,10$ & 9,10 & & \\
\hline & Control section & 12570 & 2116 & 1410 & 428 & 478 & 294 \\
\hline \multirow[t]{4}{*}{2} & Total Length $(\mathrm{Km})$ & 1253.16 & 14.9 & 164.8 & 100.06 & 113.8 & 50.26 \\
\hline & Treatment year & $\mathrm{I}, 2,3,4,5$ & 2,3 & $1,2,3,4,5$ & $\mathrm{I}, 2,3,4,5$ & $3,4,5,6$ & 4,5 \\
\hline & & $6,7,8,9,10$ & & $6,7,8,9,10$ & $7,8,9,10$ & $7,8,10$ & 6,7 \\
\hline & Control section & 6814 & 1660 & 5908 & 2590 & 2734 & 1112 \\
\hline
\end{tabular}


Table Continued....

\begin{tabular}{|c|c|c|c|c|c|c|c|}
\hline Route & & One cheap seal & Double cheap seal & Micro surfacing & Minor rehab. & Major rehab. & Reconstruction \\
\hline \multirow[t]{4}{*}{7} & Total Length $(\mathrm{Km})$ & 2246.26 & 1689.06 & 27.28 & 32.8 & 3.84 & 3.2 \\
\hline & Treatment year & $5,6,7$ & 3 & $1,2,4,5$ & 2,8 & 3,5 & 6 \\
\hline & & 9,10 & & 6,8 & 9,10 & & \\
\hline & Control section & 466 & 34 & 912 & 718 & 230 & 8 \\
\hline \multirow[t]{4}{*}{15} & Total Length $(\mathrm{Km})$ & 2985.06 & 0.56 & 100.14 & 58.24 & 4.36 & 5.1 \\
\hline & Treatment year & $5,7,8$ & 3 & $\mathrm{I}, 2,3,4,6$ & I,2,3, & 3,8 & 4,6 \\
\hline & & 9,10 & & $7,8,9,10$ & $5,9,10$ & & \\
\hline & Control section & 542 & 10 & 2384 & 1384 & 22 & 208 \\
\hline \multirow[t]{3}{*}{16} & Total Length $(\mathrm{Km})$ & 1.44 & 1.48 & 2.64 & 5.18 & 6.96 & 14.48 \\
\hline & Treatment year & $5,7,8$ & 3 & $4,6,8$ & 3 & 3,5 & 4 \\
\hline & Control section & 14 & 10 & 42 & 410 & 10 & 6 \\
\hline \multirow[t]{4}{*}{102} & Total Length $(\mathrm{Km})$ & 3.68 & & 121.22 & 126.76 & 1.8 & 5.8 \\
\hline & Treatment year & $4,5,6$ & & I, $2,3,4,5$ & I,2,7, & 3,4 & 5 \\
\hline & & & & $6,7,8,9,10$ & $8,9,10$ & & \\
\hline & Control section & 46 & & 436 & 392 & 84 & 28 \\
\hline \multirow[t]{4}{*}{104} & Total Length $(\mathrm{Km})$ & 1697.8 & & 80.48 & 48.78 & 5.34 & \\
\hline & Treatment year & 10 & & $2,3,4,6$ & I,3,4 & 7 & \\
\hline & & & & $7,8,9$ & 9,10 & & \\
\hline & Control section & 20 & & 180 & 114 & 6 & \\
\hline
\end{tabular}

This study then estimated the GHGs emissions from the pavement maintenance operations. The main GHGs in the field of pavement treatment are $\mathrm{CO}_{2}$, nitrous oxide and methane. ${ }^{23}$ Since the contribution of these gases is not the same, their 100-year 'Greenhouse Warming Potential $(G W P)$ (1 for $\mathrm{CO}_{2}, 310$ for nitrous oxide and 21 for methane)

was expressed as a $\mathrm{CO}_{2} \mathrm{e}$ (IPCC 2007). The $\mathrm{CO}_{2} \mathrm{e}$ of GHGs emissions from the selected pavement treatments (chip seal, micro-surfacing, Minor rehabilitation, major rehabilitation and reconstruction) was calculated in Table 4 .

Table $4 \mathrm{CO}_{2}$ e GHGs emissions (metric tons) for different pavement treatments required for selected routes

\begin{tabular}{|c|c|c|c|c|c|c|c|c|}
\hline Treatment & Details & Route I & Route 2 & Route 7 & Route 15 & Route 16 & Route 02 & Route 104 \\
\hline \multirow[t]{2}{*}{ Chip seal } & $\begin{array}{l}\text { Emulsion }\left(2.0 \mathrm{~L} / \mathrm{m}^{2}\right) \text {, aggregate } \\
21 \mathrm{~kg} / \mathrm{m}^{2}\end{array}$ & 389054 & 68924 & 123544 & 164178 & 79 & 202 & 93379 \\
\hline & $\begin{array}{l}\text { Emulsion }\left(1.6 \mathrm{~L} / \mathrm{m}^{2}\right) \text {, aggregate } \\
15 \mathrm{~kg} / \mathrm{m}^{2}\end{array}$ & 311243 & 55139 & 98835 & 131343 & 63 & 162 & 74703 \\
\hline \multirow[t]{2}{*}{ Micro-surfacing } & $\begin{array}{l}\text { Type III (I2\% emulsion) (13 kg/ } \\
\left.\mathrm{m}^{2}\right)\end{array}$ & 616 & 5438 & 900 & 3305 & 87 & 4000 & 2656 \\
\hline & $\begin{array}{l}\text { Type II (14\% emulsion) }(8.7 \text { kg/ } \\
\left.\mathrm{m}^{2}\right)\end{array}$ & $4 I I$ & 3626 & 600 & 2203 & 58 & 2667 & |77| \\
\hline \multirow[t]{2}{*}{$\begin{array}{l}\text { Double Chip seal (two } \\
\text { layer) }\end{array}$} & $\begin{array}{l}\text { Emulsion }\left(4.0 \mathrm{~L} / \mathrm{m}^{2}\right) \text {, aggregate } \\
42 \mathrm{~kg} / \mathrm{m}^{2}\end{array}$ & 4928 & 1639 & 185797 & 62 & 163 & 0 & 0 \\
\hline & $\begin{array}{l}\text { Emulsion }\left(3.2 \mathrm{~L} / \mathrm{m}^{2}\right) \text {, aggregate } \\
30 \mathrm{~kg} / \mathrm{m}^{2}\end{array}$ & 3942 & 1311 & 148637 & 49 & 130 & 0 & 0 \\
\hline \multirow[t]{2}{*}{$\begin{array}{l}\text { Minor Rehab./ hot in- } \\
\text { place recycling (HIR) }\end{array}$} & $\begin{array}{l}\text { Thickness } 3.8 \mathrm{~cm}(50 / 50 \text { recycle/ } \\
\text { new) }\end{array}$ & 4800 & 41825 & 13710 & 24344 & 2165 & 52986 & 20390 \\
\hline & $\begin{array}{l}\text { Thickness } 5.0 \mathrm{~cm}(50 / 50 \text { recycle/ } \\
\text { new) }\end{array}$ & 6188 & 53932 & 17679 & 31391 & 2792 & 68324 & 26292 \\
\hline \multirow[t]{2}{*}{$\begin{array}{l}\text { Major Rehab. (hot mix } \\
\text { asphalt) }\end{array}$} & $100 \mathrm{~mm}$ overlay & 208824 & $14 \mid 453$ & 4773 & 5420 & 8651 & 2237 & 6638 \\
\hline & $75 \mathrm{~mm}$ overlay & 157080 & 106403 & 3590 & 4077 & 6508 & 1683 & 4993 \\
\hline Reconstruction & $\begin{array}{l}100 \mathrm{~mm} \text { HMA overlay, } 150 \mathrm{~mm} \\
\text { aggregate base }\end{array}$ & 7839 & 72425 & 4611 & 7349 & 20866 & 8358 & 0 \\
\hline
\end{tabular}


The total $\mathrm{CO}_{2}$ e GHGs emissions from single chip sealing of the pavement surface will be $671,488.4$ to $839,360.5$ metric tons for $15,261 \mathrm{~km}$ of selected highways depending on the amount of emulsion (2liter $/ \mathrm{m}^{2}$ or 1.6 liter $\left./ \mathrm{m}^{2}\right)$ and aggregate $\left(21 \mathrm{~kg} / \mathrm{m}^{2}\right.$ or $\left.15 \mathrm{~kg} / \mathrm{m}^{2}\right)$ used in the chip sealing. For double chip sealing of the pavement surfaces, the total $\mathrm{CO}_{2}$ e GHGs emissions will be $154,070.4$ to 192,588 metric tons since the length of pavement requiring double chip sealing treatment will be $1952 \mathrm{~km}$ during the period of 30 years. $\mathrm{CO}_{2}$ e GHGs emissions from micro-surfacing of pavement surface may vary based on the type of micro-surfacing. Type III $\left(12 \%\right.$ emulsion, $\left.13 \mathrm{~kg} / \mathrm{m}^{2}\right)$ microsurfacing of $515.24 \mathrm{~km}$ pavement surface will emit 17,002.92 metric tons $\mathrm{CO}_{2}$ e GHGs in the atmosphere, which will be 11335.28 metric tons for Type II $\left(14 \%\right.$ emulsion, $\left.8.7 \mathrm{~kg} / \mathrm{m}^{2}\right)$ micro-surfacing of the same pavement surface (Table 4 ).

The total $\mathrm{CO}_{2}$ e GHGs emissions from Hot In-place Recycling (HIR) of the pavement surface will be $160,219.4$ to $206,598.7$ metric tons for $383.3 \mathrm{~km}$ pavement depending on the Thickness $3.8-5.0 \mathrm{~cm}$ (50/50 recycle/new) of the HIR. For $100 \mathrm{~mm}$ or $75 \mathrm{~mm}$ Hot Mix Asphalt overlay of $304.1 \mathrm{~km}$ pavement surface, a total of $284,333.5$ metric tons or $377,996.3$ metric tons of $\mathrm{CO}_{2}$ e GHGs will be emitted in the atmosphere during the period of 30 years (Table 4). A total $84.28 \mathrm{~km}$ of pavement surface will require reconstruction $(100 \mathrm{~mm}$ Hot Mix Asphalt overlay, $150 \mathrm{~mm}$ aggregate base) during the period of 20122041. For this reconstruction of the pavement surface, the total $\mathrm{CO}_{2} \mathrm{e}$ GHGs emissions will be 121,447.48metric tons (Table 4). Therefore, the total $\mathrm{CO}_{2}$ e GHGs emissions from different types of pavement surface treatments, due to deterioration by interprovincial truck flow, will be within the range of 1.403 million metric tons to 1.755 million metric tons depending on the type of treatments.

\section{Conclusion}

The integration of trade, transportation and environmental considerations requires a rational middle ground focusing on the environmental effects of trade and induced transportation so that trade and transportation can be part of the policy arsenal aimed at the common goal of sustainable development. The objective of this study was to integrate interprovincial trade flow induced freight movement, highway pavement maintenance, and corresponding environmental effects during the period of 2012-2041. The integration of spatial input-output and transportation modeling estimated that trucks would travel 334.722million truck-km per year for trade flow among selected provinces during the design period. The predicted truck movement resulted in an AADTT of 2397 for highway 1, 8008 for highway 2, 934 for highway 7, 599 for highway 15, 569 for highway 16, 226 for highway 102, and 183 for highway 104.

The necessary pavement surface treatments of selected routes were determined based on the mechanistic modeling of roughness progression (International Roughness Index). During the projected period (2012-2041), 15,261.1 km of pavement will require chip sealing, while $515.24 \mathrm{~km}, 1952 \mathrm{~km}, 383.3 \mathrm{~km}, 304.1 \mathrm{~km}$, and $84.28 \mathrm{~km}$ of pavement will require micro-surfacing, double chip sealing, hot in-place recycling, major rehabilitation (hot mix asphalt), and reconstruction respectively. The fuel consumption for truck movement and pavement surface treatments will cause 2.682-3.034million metric tons of $\mathrm{CO}_{2}$ e GHGs emissions depending on the type of treatments applied on the pavement surface. These predicted environmental impacts of interprovincial trade flow should encourage the incorporation of the environmental costs within the calculation of trade flows in order to ensure sustainable regional economy.

\section{Acknowledgements}

None.

\section{Conflict of interest}

The author declares no conflict of interest.

\section{References}

1. Statistics Canada. Canadian Vehicle Survey: Annual. 2009.

2. Bleijenberg A. The Driving Forces behind Transport Growth and their Implications for Policy. Belgium: OECD Publications Service; 2003. p. 37-50.

3. Amador-Jimenez LE, Amin MSR. Simulating Freight-traffic between Atlantic Canada and Quebec to Support Pavement Management on New Brunswick's Regional Highway. Journal of Infrastructure Systems. 2013;19(3):343-350.

4. Schiller PL, Bruun EC, Kenworthy JR. An Introduction to Sustainable Transportation: Policy, Planning and Implementation. Washington DC: Earth scan; 2010.

5. Amador-Jiménez L, Mrawira D. Capturing variability in pavement performance models from sufficient time-series predictors: a case study of the New Brunswick road network. Canadian Journal of Civil Engineering. 2011;38(2):210-220.

6. Flintsch GW. Life-Cycle Assessment as a Tool for Sustainable Transportation Infrastructure Management. In: Kutz M, editor. Environmentally Conscious Transportation. USA: John Wiley and Sons Inc; 2008. p. 257-282.

7. Zhang H, Keoleian GA, Lepech MD. An integrated life cycle assessment and life cycle analysis model for pavement overlay systems. In: Biondini, Frangopol, editors. Life-Cycle Civil Engineering. UK: Taylor \& Francis Group; 2008. p. 907-912.

8. Dorchies PT. The Environmental Road of the Future: Analysis of Energy Consumption and Greenhouse Gas Emissions. Toronto: Transportation Association of Canada; 2008.

9. Chappat M, Bilal J. The Environmental Road of the Future: Life Cycle Analysis, Energy Consumption and Greenhouse Gas Emissions. 2003.

10. Chevoits J, Galehouse L. Energy Usage and Greenhouse Gas Emissions of Pavement Preservation Processes for Asphalt Concrete Pavements. USA: Institute of Transportation Studies, University of California; 2010. p. $27-42$.

11. Terrel RL, Hicks RG. Viability of Hot In-Place Recycling as a Pavement Preservation Strategy. USA: California Pavement Preservation Center, Chico; 2008

12. Miller T, Bahia H. Sustainable Asphalt Pavements Technologies, Knowledge Gaps and Opportunities. USA: Modified Asphalt Research Center, University of Wisconsin Madison; 2009.

13. Vickerman R, Monnet J. Freight Traffic. Managing the Fundamental Drivers of Transport Demand. UK: OECD Publications Service; 2003. p. $15-25$.

14. Amador L, Mrawira D. Measuring the Benefits of Integral Management of Road Networks: New Brunswick's Highways, Bridges and Culverts. Proceeding of $91^{\text {st }}$ Annual meeting of the Transportation Research Board. Washington DC, USA; 2011.

15. Amin MSR, Amador LE. Travel demand modeling to simulate traffic loads for pavement deterioration curves: dealing with aggregate data at urban and regional scales. Canadian Journal of Civil Engineering. 2015;42:1049-1062. 
16. Ministry of Transportation. Trans-Canada Highway 1-Malahat Corridor Study. Final Report. British: Ministry of Transportation; 2007.

17. Levinson D, Corbett M, Hashami M. Operating costs for trucks. 2005.

18. Economic Analysis Directorate. Operating Costs of Trucks in Canada 2005. Calgary: Transport Canada; 2005.

19. Modelistica. Mathematical Descriptions of TRANUS. 2008.

20. Transportation Business Association. Operational Costs-Reducing Fuel Use is being Green. 2011.

21. Transportation Research Board. Truck Trip Generation Data. A Synthesis of Highway Practice. USA: National Academy Press; 2001.

22. Amin MSR, Amador LE. Pavement management with dynamic traffic and artificial neural network: a case study of Montreal. Canadian Journal of Civil Engineering. 2016;43(3):241-251.

23. Canadian Construction Association. Road Rehabilitation Energy Reduction Guide for Canadian Road Builders. 2005.

24. National Highway Traffic Safety Administration. Light-Duty Vehicle Greenhouse Gas Emission Standards and Corporate Average Fue Economy Standards, Final Rule. Federal Register. 2010;75(88):25-330.

25. Gakenheimer R. The Automobile and the Environment: An International Perspective. UK: MIT Press; 1978.

26. IPCC. Climate Change 2001: The Scientific Basis. UK: Cambridge University Press; 2001.

27. Keoleian GA, Spitzley DV. Sustainability science and engineering. Netherlands: Elsevier; 2006.
28. LCPC-SETRA. Le guide technique de conception et dimensionnement des chausses. France: LCPC-SETRA; 1994.

29. Mrawira D, Amador L. Cross-Assets Trade-off Analysis: Why are we still talking about it? Procceding of $88^{\text {th }}$ Annual Meeting of the Transportation Research Board. Washington DC, USA; 2009.

30. Natural Resources Canada. The National Atlas of Canada 1978-1995. Thornthwaite Classification Moisture Regions. 1995.

31. Newman PWG, Kenworthy JR. Sustainability and Cities: Overcoming Automobile Dependence. Washington DC: Island Press; 1999.

32. Paterson WDO, Attoh-Okine B. Summary of Models of Pavement Road Deterioration Based on HDM-III. Journal of the Transportation Research Board. 1992;1344:99-105.

33. Stringer P, Wenzel H. Transportation Planning for a Better Environment. USA: Plenum Press; 1976.

34. Stripple H. Life Cycle Inventory of Asphalt Pavements. Sweden: IVL Swedish Environmental Research Institute Ltd; 2000.

35. The Athena Sustainable Materials Institute. A Life Cycle Perspective on Concrete and Asphalt Roadways: Embodied Primary Energy and Global Warming Potential. Canada: Canadian Portland Cement Association; 2006.

36. Watanatada T, Harral CG, Paterson WDO, et al. The Highway Design and Maintenance Standard Model. USA: The John Hopkins University Press; 1987. 